\title{
TECNOLOGICAL EVOLUTION OF SUGARCANE PROCESSING FOR ETHANOL AND ELECTRIC POWER GENERATION
}

\author{
Manoel Regis Lima Verde Leal
}

\section{INTRODUCTION}

Brazil has a long tradition in the cultivation and processing of sugarcane for sugar production and already in the beginning of the $20^{\text {th }}$ Century started to give the first steps toward the path of ethanol production. The electric power generation using bagasse went slower, initially aiming at reaching the energy self-sufficiency, and only in the last ten years the generation of surplus power for sale became an irreversible trend. However, Brazil has not been a reference in terms of technology and competitiveness all the time. Looking back from the dawn of the $20^{\text {th }}$ Century to the present time one can see difficulties and adverse situations faced by the sugarcane sector as well as the impacts of the National Ethanol Program Proálcool, launched in November 1975.

Before the Proálcool, the ethanol production was aimed mainly at reducing the offer of sugar by deviating the sugarcane surplus to this new product, to be added to the gasoline on an available basis, but normally around 5\% by volume. Besides the excess of production the sector also suffered from low competitiveness in the international market, both in the agricultural and industrial areas, due to lack of technological reference, in spite of the fact that the government in several occasions had made available low interest loans for modernizing the mills. The creation of Copersucar - Cooperative of Sugarcane, Sugar and Alcohol Producers, at the end of the 1950s, offered an opportunity to consider technological improvements due to the necessity to increase the competitive- ness, necessary for survival, based on the size and economic power of the new cooperative. Thus, at the beginning of the 1970s, a sugarcane breeding program was initiated; an analysis laboratory for quality control and a technical department to support the cooperative mills were created. In 1972 the Federal Government created also the Planalsucar, a full program targeted to stimulate the technological development of the whole sugarcane sector, with a major focus in the genetic improvement of sugarcane.

In the industrial area, the technology development was pushed by the Proálcool, with different focus in each one of its many phases. In the initial phase, from 1975 to 1979 , the necessity to increase production to meet the Government established targets of 3 billion liters in 1980 and 10.7 billion liters in 1985, starting from the almost 600 million liters produced in 1975, induced the development of technologies to essentially increase plant throughput. In this period the ethanol production increase was achieved by annexing distilleries to existing sugar mills, but deviating from the normal way to use only exhausted molasses as feedstock for the distillery; sugarcane juice started to be mixed with the molasses that had its purity increased in the sugar factory. Therefore, the main pressure was in the common areas of the sugar/ ethanol mill that were the juice extraction and steam and power generation systems. This production increase took place without much concern about factory efficiency or useful life of equipment more directly affected. With the second oil shock in 1979, the Government realized that it was neces- 
sary to accelerate further the production increase and the ethanol blending with the gasoline model should be supplemented with the production of hydrous ethanol to be used in engines specifically developed or adapted for this fuel that should start to be manufactured by the auto industry.

The auto makers responded quickly, offering to the market the first model fueled with neat hydrous ethanol already in 1979; however, it was really in 1983 when the first engine optimized to burn hydrous ethanol was produced, taking advantage of several favorable characteristics of this fuel (higher octane numbers, higher latent heat of vaporization, faster and colder burning) and solving problems associated with the initial disadvantages of ethanol fuel, such as cold start. The mill owners acted also adequately installing autonomous distilleries that produced only ethanol, from the juice directly from the milling tandem. In this second Proálcool phase, from 1980 to 1985, two new facts happened: the entrance of new entrepreneurs in the sugarcane sector from outside the sector, and the accelerated construction of new distilleries (ANNICCHINO, 1985). The concern about efficiency and productivity gained strength initiating a new phase of technology development. The targets set for 1980 and 1985 are easily met and even surpassed.

In 1986 the so called cold oil shock took place with a strong decrease of oil prices for values close to the 1978 levels. Petrobras had also done its job, increasing considerably the national oil production, thus reducing the need for imports. In this way the interest of the Government in the Proálcool dwindled and the subsidies were slowly reduced, decreasing the competitiveness of ethanol with respect to gasoline; as a consequence the rate of growth of the production was significantly reduced to close to zero leading to the third phase that can be called of stagnation that lasted until the beginning of this century. During this period the sugarcane sector was hit by several crises and in 1990 the Institute of Sugar and Alcohol - IAA, that controlled the whole sector, was extinct leading to the start of the deregulation process with the Government pulling out of the production and market control. The economic hardship that re- sulted from the gradual elimination of subsidies of all sorts caused the bankruptcy of the less efficient and capable producers and their mills and cane fields were taken over by better prepared sector entrepreneurs that could face the falling ethanol prices; the gains in scale, with the incorporation of the bankrupted mills to the surviving ones, and the development of more modern attitudes, concerned with efficiency and production cost reduction, pushed the technology development forward at a faster pace to reach the level of competitiveness of today. Prior to the extinction of IAA the country exported, under Government control, around one million tons of sugar per year; under a totally private control of the industry the sugar exports reached the present level of more than 20 million tons per year, and growing. It was this growth in sugar exports that helped the sugarcane sector to survive through the Proálcool stagnation phase and the necessity of competitiveness without subsidies was the main drive for the technology development and management improvement. Finally, the last phase of the ethanol cycle in Brazil that started around 2002 with the increase in oil prices was definitely consolidated by the introduction in the market of the Flexible Fuel Vehicle - FFV in 2003.

The dissemination of information and media focus on the problems associated with the climate change, together with the negative impacts of fossil fuels use on the greenhouse gas - GHG emissions, have increased the interest in biofuels in general and ethanol in particular. However, it is the volatility of oil prices and concerns with the security of supply of this fossil resource that have, in fact, motivated the use of ethanol as a fuel. Therefore, the ethanol technological development must continue at an accelerated pace aiming at the production cost reduction and the improvement of the sustainability indicators, specially the GHG emission reduction potential; this is the only way the keep sugarcane ethanol as one of the best options to partially replace fossil transportation fuels and to reduce the GHG emissions, when compared to the other alternatives.

The description of the technological evolution in the sugarcane processing to ethanol will be presented below, covering the period from the 
launching of the Proálcool until today. At the end, a list of suggestions will be presented on how to improve further the technical-economic viability of ethanol as a substitute for transport fossil fuels and to mitigate the climate change.

\section{TECHNOLOGICAL DEVELOPMENT IN THE PRODUCTION OF ETHANOL}

To facilitate the understanding of the evolution process in the mills and distilleries, the sugarcane processing path was divided into sectors and each one described separately, covering from the sugarcane reception to energy generation to supply the plant needs. Conventionally the distilleries are split into the following sectors: Cane Reception/Preparation/Juice Extraction, Juice Treatment, Fermentation, Distillation/Dehydration and Energy. The water and effluent treatment systems, as well as the ethanol storage and handling, will not be treated here.

\section{Sugarcane reception, preparation and juice extraction}

This is one of the most important sectors in the distilleries due to the high capital investment required, high operation and maintenance costs, high energy consumption and impact on the global plant efficiency. A sequence of heavy duty equipment forms this system fed and interconnected by belt conveyors for sugarcane and bagasse; therefore the overall performance depends not only on the individual performance of each equipment, but also on a well designed and optimized sequence of operations.

Even before the launching of Proálcool it was recognized that the cane preparation and juice extraction technology in use in Brazil was inefficient and obsolete (CTC, 1983). Copersucar, with its economic capacity and modern entrepreneurial vision, was the first institution to react to improve this situation: organized a technical group in 1974 and contracted the consulting of the South African specialist Deon Hulett (South Africa and Australia were considered, at that time, the technological reference for sugarcane processing for sugar) to start the process of developing a modern cane preparation and juice extraction technology, ef- ficient, highly productive and well adapted to the Brazilian conditions. The concept of standardization was introduced since the beginning of the work and milling was selected as the juice extraction system since it was already the most widely used in the country (CTC, 1983). The result of this effort was a set of main and auxiliary equipment perfectly integrated and optimized as a whole and standardized to facilitate the manufacture and maintenance. The main technological improvements in this sector will be described in sequence.

\section{Cane reception}

The necessity to unload the cane from the trucks quickly led to the selection of the spiller (hilo) as the equipment to be developed and it was widely adopted by the mills together with one of the concepts of cane feeding tables: conventional, $45^{\circ}$ and $35^{\circ}$. The choice of the feeding table option was based in a case by case evaluation depending on the existing equipment, space available, type of harvesting and cane transportation system; the conventional table, with an slope angle up to $18^{\circ}$, started to loose ground in the competition against the two other alternatives that had higher feeding capacity, provided a thinner and more uniform cane layer, facilitating the cane washing operation and efficiency, and resulted in a larger reduction in the cane mineral impurity levels. It is important to point out that the feeding table is a key item to facilitate the operation of the cane preparation and juice extraction equipment by providing a uniform and continuous cane layer.

With the increase of mechanical harvesting the feeding table design suffered several modifications to adapt it to receive also chopped cane; in this case, the changes to improve the removal of mineral impurities were very important since chopped cane cannot be washed like whole cane, due to the resulting high sugar losses.

Besides the main equipment some auxiliary ones, like the straw cush-cush (a type of screen used to separate the straw and pieces of cane from the washing water), the metallic and belt conveyors, leveler and electro-magnet. All these items had to be adapted to the increased capacity of the new juice extraction systems. 


\section{Cane preparation}

With the understanding of the importance of cane preparation to the efficiency of juice extraction and to the capacity of the milling tandem, the concept of the systems in use at that time was totally modified. A quality of cane preparation is measured by the percentage of open cells in the prepared cane, named cane preparation index; for a good extraction efficiency in the milling tandem, it was established that the preparation index must be above $80 \%$, calling for the use of a shredder in the system. The cane preparation system was then standardized with one set of knives (a rotor with a set of blades), to chop the cane, and a shredder both assembled on the metallic conveyor, between the feeding table and the milling tandem. For higher milling rates it was recommended that an additional set of knives in front of the set to act as a cane layer leveler.

The Copersucar Technology Center - CTC developed standardized designs for all these items covering the range of milling capacities commonly used by the mills, resulting in the knives COP 8 and COP 9 and shredders COP 5 and COP 6, besides the heavy duty model COP 10 for higher preparation indices (CTC, 1990). This set of equipment allowed the mills to operate with preparation indices in the $80 \%$ to $85 \%$ range, or even $90 \%$ to $92 \%$ in the case of COP 10 . All these items were designed with fixed or swing blades (knives) and swing hammers (shredders) with a deposit of hard weld on the impact surfaces to increase the life of the most demanded parts of the equipment.

\section{Milling}

The main focus in the development of the milling technology was on the increase in capacity and extraction efficiency, since this sector was normally the main bottleneck for the expansion of the mill production and also, together with the fermentation, was one of the main areas of sugar losses in the cane processing. The main items developed for these purposes were feeding chute (or Donnelly chute), the press roll, the imbibition system, the feed roll, the weld deposits on the grooves (on the teeth sides), the conveyor between mills, the modification and reinforcement of some critical components (like mill shaft and headstock) and, last but not least, automation (CTC, 1990).

The Donnelly chute is a type of vertical duct with variable rectangular section installed at the inlet of the mill to create a column of prepared cane or bagasse to increase the pressure, by gravity, at the mill inlet. Besides the resulting increase in milling capacity this chute became the key item in the mill control system, with the cane height inside it being the variable used to optimize the speeds of the cane conveyor and mill rolls. Whenever the existing layout would allow the Donnelly chute should be installed at the inlet of each mill; in case where space problems exist, at least the first mill should be fitted with such equipment. Figure 1 shows the installation of a Donnelly chute, where the cane level sensors for the control system can be seen on the side of the chute.

The pressure roll, or $4^{\text {th }}$ roll, became a standard item in the Brazilian mills. Together with the feed roll and the Donnelly chute it forms the set designed to increase the capacity of the existing and new milling tandems. The hard weld deposits on the tip and sides of the roll shell grooves help to drag the cane and bagasse between the rolls, thus allowing the mill to process the additional cane pushed trough by the previously described equipment. The imbibition system is a key component in the effort to increase the juice extraction efficiency. Since the mill cannot reduce the bagasse moisture to levels much lower than $50 \%$ it was necessary to develop a system that permitted the dilution of the juice retained in the bagasse, thus inducing the use of the concept of imbibition. There are three possible types of imbibition: simple, compound and with recirculation, with increasing efficiency in that order; due to practical reasons the compound imbibition became the most widely used option, where water is added to the bagasse at the inlet of the last mill, fulling soaking it, and from there on the juices from the other mills are added to the cane entering the upstream mill in such way that the imbibition liquid goes counterflow with the cane in the milling tandem.

Besides these main items it also became necessary to develop several auxiliary items and components to make it possible to reach the performance 


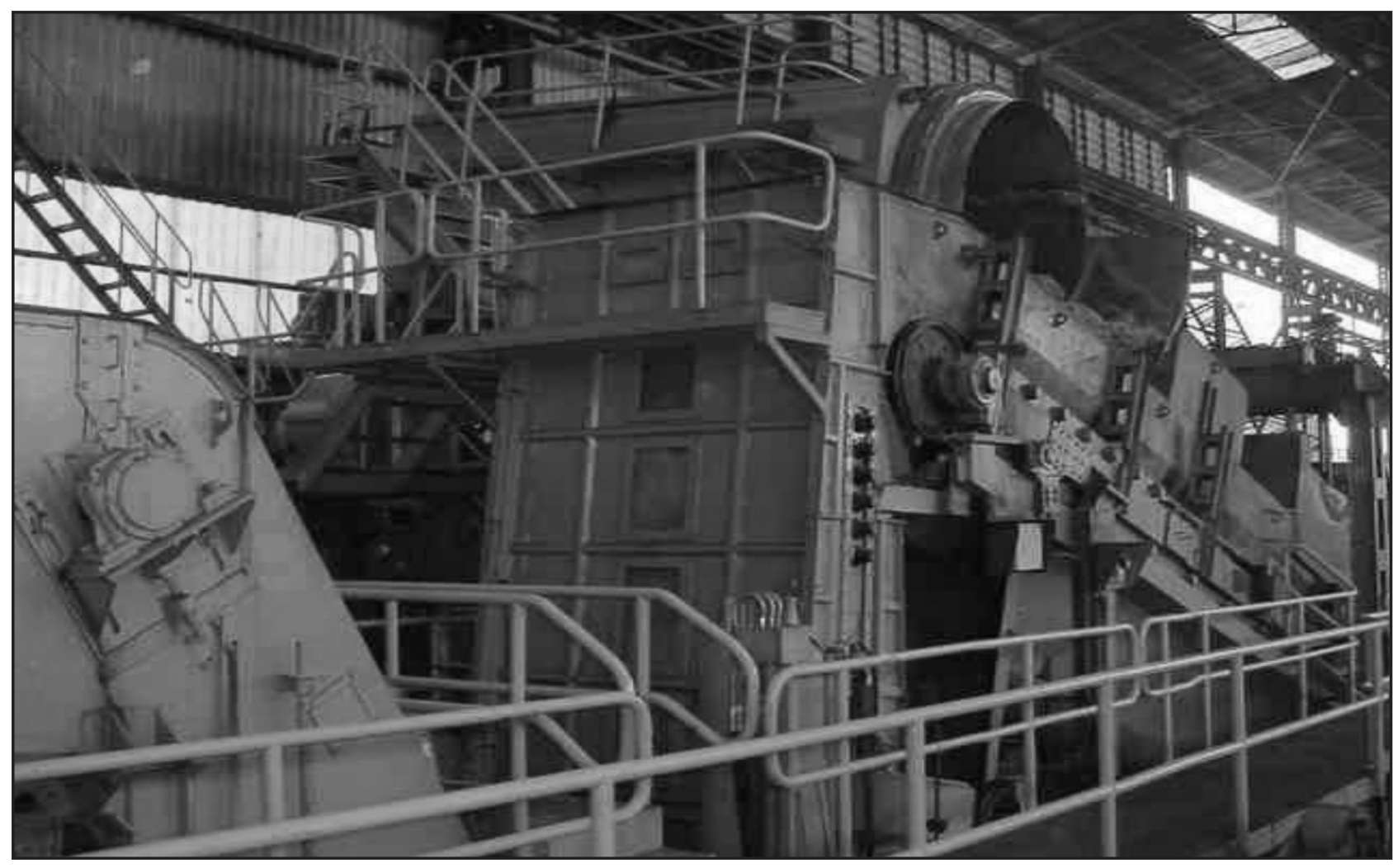

FIGURE 1 Donnelly chute installation at the first mill inlet.

levels of today. The role of CTC and equipment manufacturers was fundamental in this process.

Tables 1 and 2 present a summary of the technological evolution of the juice extraction system in Brazil in terms of milling capacity increase and juice extraction efficiency, respectively, showing the participation of each technology in the process (DELFINI, 2004).

It is possible to see in the Tables below that the technological evolution of the juice extraction system was by steps and significant as a whole, involving a very large number of improvements combined and incremental, that demanded a lot of time, dedication and resources. Comparing the present Brazilian juice extraction system with the Australian and South African models, that have been used in the initial phase as the basis for the development, our system have reached extraction efficiency levels very close to the Australian and South African ones, but at a much lower investment and operational costs due to the higher capacity of our mills when compared with the same gage (width) mills in Australia and South
Africa. Somehow, the juice extraction technology in Brazil has reached such an advanced level that has inhibited the development of promising alternatives such as the hydrodynamic extraction system that started to be developed at CTC, based on a Reunion Island patent, and was discontinued.

\section{Juice treatment system}

Prior to Proálcool, and even in the beginning of its first phase, the treatment of the juice as extracted by the mills did not received much attention from the sector, since the ethanol was produced mainly from exhausted or partially exhausted molasses. With the start of the second phase in 1980 along with the installation of autonomous distilleries in a very fast pace, the juice started to be sent directly from the mills without any treatment - called raw juice. With the improvement of the knowledge of fermentation microbiology it was possible to correlated several fermentation problems with the dirt and contaminants carried by the raw juice, thus inducing the search for 
TABLE 1 Evolution of the milling capacity.

\begin{tabular}{|c|c|c|c|c|c|}
\hline \multirow{2}{*}{$\begin{array}{c}\text { Mills } \\
\text { (width) }\end{array}$} & \multicolumn{5}{|c|}{ Technology evolution phases (milling capacity in tons of cane/h) } \\
\hline & Original & $\mathbf{I}$ & II & III & IV \\
\hline 54 inches & 130 & 180 & 190 & 210 & 280 \\
\hline 78 inches & 270 & 375 & 400 & 440 & 580 \\
\hline
\end{tabular}

Note: Technology evolution phases:

I. Cane preparation + pressure roll;

II. $45^{\circ}$ feeding table + cane spreader + belt conveyor + Donnelly chute;

III. Redesign of conventional headstocks;

IV. Special headstocks ( $1^{\text {st }}$ e $2^{\text {nd }}$ mills) - larger mill roll diameters.

Source: DELFINI (2004).

TABLE 2 Milling juice extraction efficiency evolution.

\begin{tabular}{|l|c|c|c|c|c|}
\hline \multirow{2}{*}{$\begin{array}{c}\text { Mills } \\
\text { (width) }\end{array}$} & \multicolumn{5}{|c|}{ Technology evolution phases (sugar extraction efficiency, \%) } \\
\cline { 2 - 6 } & Original & I & II & III & IV \\
\hline Efficiency & 91 a 93 & 93.5 a 95 & 94.5 a 96 & 96 a 97 & 97 a 97.5 \\
\hline
\end{tabular}

Note: Technology evolution phases:

I. Cane preparation + pressure roll + compound imbibitions;

II. Donnelly chute + feed automation + roll shell weld deposits;

III. Donnelly chute (all mills) + automation (all mills);

IV. Mill adjustment + mill operation control.

Source: DELFINI (2004).

economically viable and adequate ways to treat the juice; the juice treatment for sugar production was somehow used as a model, but there was the feeling that this process was too sophisticated and expensive beyond the necessary. Still in 1990, 10 years after the boom of autonomous distilleries, persisted the doubts about the best strategy to treat the juice for the fermentation (CTC, 1990) and the focus was apparently on the physical treatments to remove impurities, but the thermal shock type treatment was already being experimented to eliminate the microbiological contaminants. The treatments to remove just the coarse impurities have proved to be inefficient and at the same time it was realized the negative effects of the colloidal impurities, leading to the start of the use of clarification process. The SRI model clarifier (trayless and short retention time), whose property rights have been bought by Copersucar from the Sugar Research Institute - SRI from Australia, in spite of having not shown the expected performance for juice treatment for sugar fabrication, was tested and approved for ethanol production. The lower investment cost, compact design and adequate performance, helped to spread its use in the ethanol path and, after a learning period, it started to show a good performance for the sugar path also and became a standard equipment for juice treatment for both sugar and ethanol productions.

In general, it can be said that the juice treatment technology is at an adequate level for fermentation, but there is still a good potential for improvements, including the combination with the broth treatment.

\section{Fermentation}

With the large expansion of the ethanol production during the two first phases of Proálcool, between 1975 and 1985, this product gained a great importance both economic and strategic for the sugarcane sector. Around 1975 ethanol represented approximately $10 \%$ of the total cane processed in Brazil and the percentage reached about $70 \%$ at the end of the second phase. 
The fermentation was the step with the lowest efficiency in the whole industrial process, barely surpassing the $80 \%$ of the stoiquiometric conversion rate of 0.6474 liters of absolute ethanol per kilogram of total reducing sugars - TRS at the beginning of the expansion. Therefore it is more than justified that this process had received a high priority in the technology development effort. The most widely used process in Brazil has always been the fed batch with yeast recirculation known as the Melle-Boinot process; this process was already well known and used in several countries, including Brazil, but required a lot of study and improvements to reach the levels of productivity and efficiency obtained today. One alternative being developed in Brazil is the multi stage continuous fermentation; this development started in the 1979/1980 crushing season with the adaptation of the batch fermentation facilities of the Porto Feliz mill for a multi stage continuous fermentation. In 1983 the Cresciumal mill installed a multi stage continuous fermentation designed to produce 120 $\mathrm{m}^{3}$ /day of ethanol (CTC, 1983). At some period of time around $30 \%$ of the total ethanol produced in Brazil came from continuous fermentations; today this percentage has been reduced due to the difficulties in operating with this technology in the event of a large scale infection. However, the many advantages of the continuous fermentation has kept the interest in solving its problems in a high priority: lower investment costs, less space required for installation, less use of chemicals, easier automation and easier operation under normal conditions. It is reasonable to expect that it will dominate in the ethanol production in the future, once today's problems are solved.

In both technologies the knowledge of the process was basically empirical, accumulated during decades of the production of residual ethanol (from the exhausted molasses), and lacked a better scientific base to permit the optimization of the operation of the fermentations and also the quick identification of the problems as soon as they appear. CTC had, once more a very important action in this process. Analytical methodologies were developed aiming at the quantification, even by indirect means, of the fermentation yields and the presence of indicators of an incipient bacterial infection, in a reliable and economically viable way. The study of the fermentation kinetic model was started that would allow the conversion of measurements feasible by the analytical methodology in parameters and indices important to the operation control of the fermentation and to the design of new installations. Due to the long time required for the microbiological analyses and their deficiencies, the development of on line sensors was pursued for measuring parameters such as the alcohol content in the vats, wine and vinasse and the yeast concentration in the vats and in the yeast cream.

The study of new yeast stains was very important for improving the fermentations; in collaboration with the National Regional Research Center in Peoria, Illinois (USA) several tentatives were made to combine favorable characteristics of one strain with the ones of another strain through the fusion of both protoplasts (CTC, 1983). These experiments did not bring practical results but provided an evolution in the knowledge of the yeast potential. One very successful line of work was the study of yeast and bacteria population dynamics along the cane processing season; this work was facilitated and accelerated by the introduction, in the second half of the 1980's, of the Chromosome Polymorphism technology, also known by the name of "fingerprint" by analogy with the system of identification of persons by their fingerprints. This technology provides a standard of chromosomes organized in sequence by their length, through the use of electrophoresis, which is an unequivocal characteristic of each microorganism. In this way, it was possible to follow the variation of yeast populations in fermentations of several mills and to select the best performing strains, within the specific characteristics of each fermentation, (temperature, osmotic pressure, $\mathrm{pH}$, ethanol content etc.); infection problems could have their causes more easily and quickly identified. This methodology and the selected yeast strains served as basis for the development of faster and safer fermentation start up procedures.

The fermentation vat design went through several modifications to improve the geometry 
(conical bottom, elimination of flow stagnation points, better agitation), the cooling (external plate heat exchangers replacing the obsolete internal cooling coils, cooling towers to close the cooling water system, and better broth recirculation), the closing of the vats to recover the ethanol carried over by the fermentation gases. In the case of continuous fermentation, it was developed the technology for foam elimination through the carry over from one vat to the next in the line, improvement of the internal circulation and the introduction of internal compartments to facilitate the operation under low production rates.

One more recent line of work, aiming at reducing the occurrence of infections in the fermentation, develops purification techniques and thermal broth treatments prior to feeding it to the vats, optimization of biocides and antibiotics use and introduction of a vat cleaning system.

Several other improvements have been developed in this 40 year period of the Proálcool, but there is no space to describe them all. The most important results are shown in Figures 2 to 4.

From these Figures it can be seen the fast and remarkable growth of the fermentation yields from
$82 \%$ to $83 \%$ in the beginning of Proálcool to the $91 \%$ plateau at the end of the 1980s; gains in productivity measured by the reduction in fermentation time from 15 hours to 8 to 9 hour range, also in the same period. The increase in yeast concentration in the vats have brought the Brazilian values to a range well above what is practiced in other countries, shown in Figure 4, was one of the reasons for the gains in yields and productivities. These data are applicable to the best mills and could be used as reference to indicate to what level the others can reach. The leveling off the curves since the early 1990s indicates that the present technology in use has already reached a high level of maturity and the potential for incremental gains still possible is very low, but production cost reductions are still possible through the optimization of the use of chemicals and other inputs and by the elimination, or at least a drastic reduction, of the infections.

\section{Distillation and dehydration}

The distillation and dehydration technologies have been imported and supplied Brazilian equipment manufacturers as standard packages containing seven columns, grouped in four sets, and the

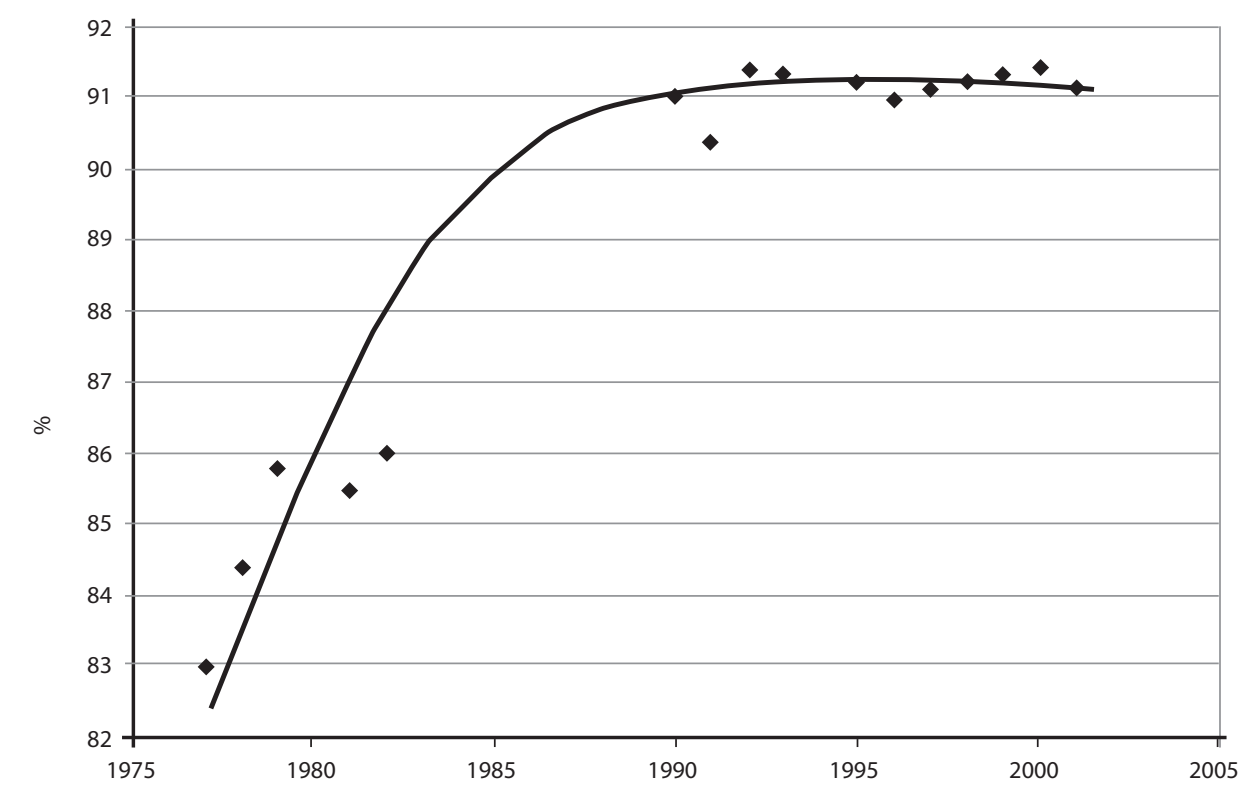

Source: FINGUERUT (2005).

FIGURE 2 Evolution of fermentation yield. 


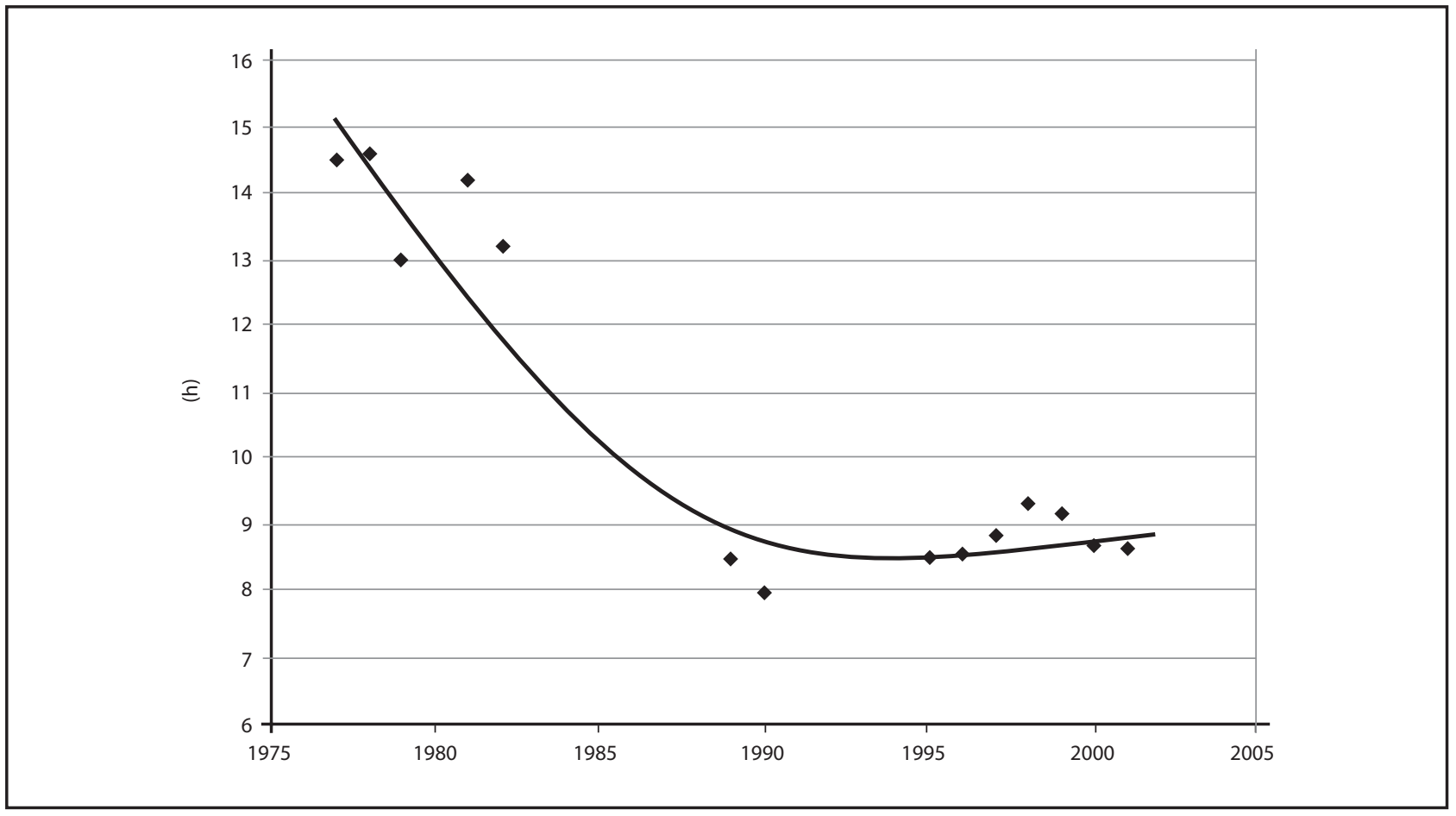

Source: FINGUERUT (2005).

FIGURE 3 Evolution of fermentation time.

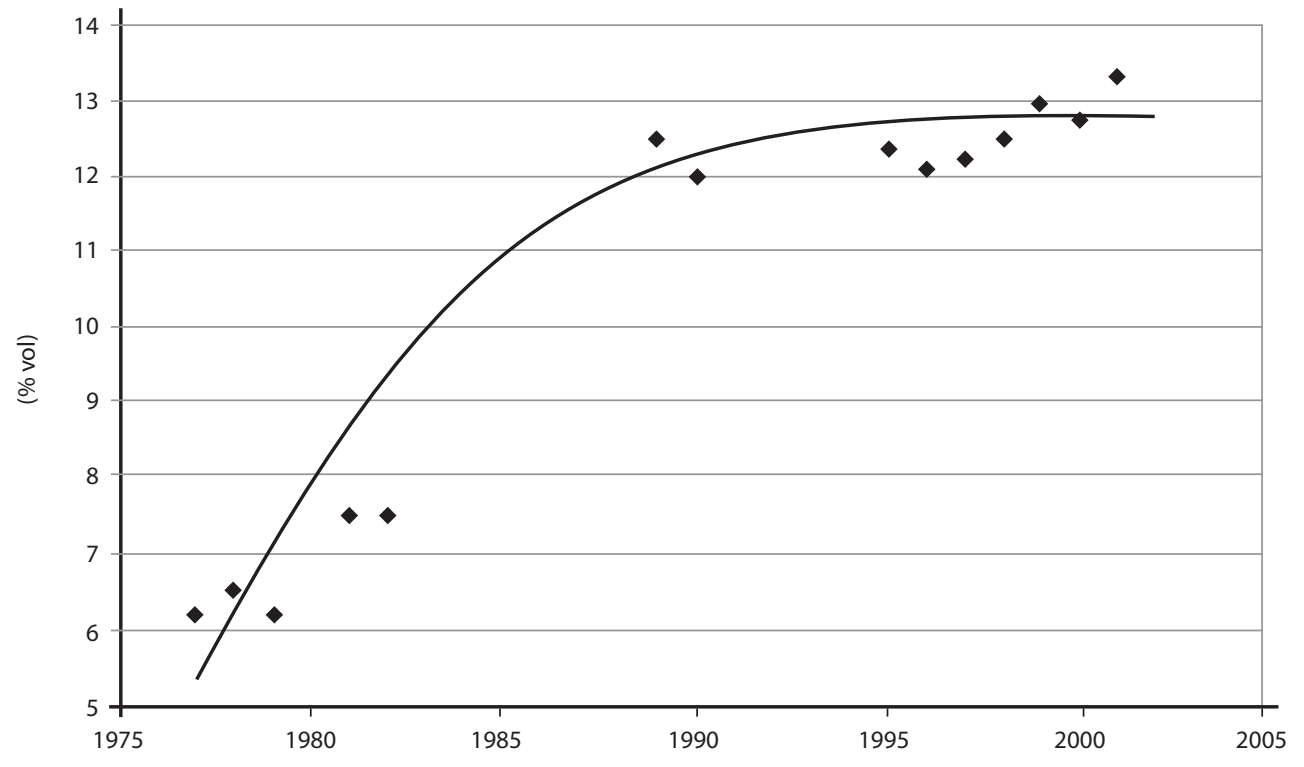

FIGURE 4 Evolution of yeast concentration in the vats.

Source: FINGUERUT (2005). 
auxiliary systems (condensers, settling tanks, heat exchangers, tanks and others). The four set are:

Distillation: formed by columns A, A1 and $\mathrm{D}$ one at the top of the other. The impurities are eliminated mainly in column D (esters and aldehydes) and ethanol is concentrated up to $40^{\circ}$ to $50{ }^{\circ} \mathrm{GL}$ (ethanol content by volume) leaving as flegma in the form of steam. The bottom product is vinasse that exchanges heat with the incoming wine as it leaves the column.

Rectification: formed by columns B and B1 with the objective to concentrate the ethanol to $96{ }^{\circ} \mathrm{GL}$, leaving as hydrous ethanol that is an azeotropic mixture of ethanol and water, which can no longer be concentrated by simple distillation. More impurities are extracted as volatile compounds and the condensates are recycled or removed as lower alcohol. The bottom product of column B1 is a spent aqueous solution named flegmasse that is recycled or eliminated from the process.

Dehydration: column C performs the operation of removal of most of the water contained in the hydrous ethanol. Up to 15 years ago the dehydrating agent was benzene, but the working safety conditions made its use very complicated, after its grading as carcinogenic substance, what caused the phasing out of its use. After several laboratory and field tests the new dehydrating agent selected was the cyclehexane. The dehydrating agent is introduced at the top of the column forming a ternary mixture dehydrating agent-water-ethanol that is heated up with steam, and the ethanol is removed from the bottom of the column as anhydrous ethanol around $99.7^{\circ} \mathrm{GL}$; the mixture waterdehydrating agent is separated in a settling tank.

Dehydrating agent recovery: column $\mathrm{P}$ has this function and the process is known in Brazil by the traditional name of "debenzolagem". The column receives the water from the settling tank of the dehydration system and by distillation recovers the solvent that is sent back to column $\mathrm{C}$.

These sectors are the largest consumers of thermal energy, or process steam, in the ethanol production process, but since bagasse has been for a long time sufficient to supply all the energy demanded by the distillery or mill this situation persisted until today. The steam consumptions (at
2.5 bar, saturated) for distillation and dehydration remain in the ranges of 3 to 3.5 and 1.5 to $2 \mathrm{~kg} / \mathrm{liter}$ of ethanol, respectively.

One of the critical problems in the beginning of the ethanol expansion growth was the large production of lower alcohol due to the necessity to produce a high quality fuel ethanol; this production could reach up to $15 \%$ of the total ethanol production in some distilleries (CTC, 1983). This product, due to its high contaminant contents such as organic acids, esters, aldehydes, higher alcohols, had a very low commercial value. Modifications in the columns were introduced in order to bring the lower alcohol level to the $3 \%$ to $4 \%$ range; these processes have been called hydroselection (column P) and "repasse" (column C). Copersucar installed a refinery for lower alcohols to process the production of this byproduct from the cooperated mills in a centralized and more economical way, creating a commercial value for it. The modifications made in the distilleries through these 40 years have reduced the production of lower alcohol close to zero.

With the introduction of neat ethanol cars in the market, the hydrous ethanol production had a sharp increase and some of the distilleries installed annexed to the sugar mills in the first phase of Proálcool had a large idle capacity in the dehydration section. A process was then developed (CTC, 1990) to use the dehydration column (column C) operating in parallel with the rectification column (column B) and introduced some modifications in the standard process; the result was an increase in the production of hydrous ethanol in the distilleries that could exceed 50\% in some cases, making this alternative widely used.

The fuel ethanol specifications in the initial phase of the production expansion were established by the Institute of Sugar and Alcohol - IAA based on the existing specifications for industrial ethanol. Table 3 shows IAA specifications for hydrous ethanol for several uses.

These specifications have shown to be insufficient for the good operation of the engines and for this reason were modified as shown in Table 4 .

The evolutions described above lead to the consolidation of an industrial process, shown in a simplified form in Figure 5, known today as the 
TABLE 3 Specifications for hydrous ethanol for various uses.

\begin{tabular}{|c|c|c|c|}
\hline Characteristics & Fuel hydrous & Non fuel hydrous & Refined hydrous \\
\hline Specific gravity at $20^{\circ} \mathrm{C}$ & 0.8076 to 0.8110 & $0.8076 \pm 0.0011$ & Max. 0.8065 \\
\hline Ethanol content ('INPM) & $93.2 \pm 0.6$ & $93.8 \pm 0.4$ & Min. 94.2 \\
\hline Fixed residues max. (mg/100 ml) & - & 5 & - \\
\hline Total acidity max. (mg/100 ml) & 3 & 3 & 1.50 \\
\hline Aldehydes max. (mg/100 ml) & 6 & 6 & 1 \\
\hline Esters max. (mg/100 ml) & 8 & 8 & 2 \\
\hline Higher alcohols max. (mg/100 ml) & 6 & 6 & 1 \\
\hline Methyl alcohol max. (mg/100 ml) & - & - & 0.2 \\
\hline Alkalinity & Negative & Negative & Negative \\
\hline Aspect & $\begin{array}{l}\text { Clear and free from } \\
\text { suspended matter }\end{array}$ & $\begin{array}{l}\text { Clear and free from } \\
\text { suspended matter }\end{array}$ & $\begin{array}{l}\text { Clear and free from } \\
\text { suspended matter }\end{array}$ \\
\hline
\end{tabular}

Source: CTC (1987).

TABLE 4 New fuel ethanol specifications, anhydrous and hydrous.

\begin{tabular}{|l|c|c|c|}
\hline \multicolumn{1}{|c|}{ Characteristics } & Units & Anhydrous & Hydrous \\
\hline Acidity (as acetic acid) & $\mathrm{mg} / \mathrm{L}$ & $<30$ & $<30$ \\
\hline Electric conductivity & $\mathrm{microS} / \mathrm{m}$ & $<500$ & $800.3 \pm 1.7$ \\
\hline Specific gravity & $\mathrm{kg} / \mathrm{m}^{3}$ & $<791.5$ & $93.2 \pm 0.6$ \\
\hline Ethanol content & $\% \mathrm{v} / \mathrm{v}$ & - & $6 \mathrm{a} 8$ \\
\hline $\mathrm{pH}$ & - & - & $<5$ \\
\hline Evaporation residue & $\mathrm{mg} / 100 \mathrm{~mL}$ & - & $<1$ \\
\hline Chloride ion & $\mathrm{mg} / \mathrm{kg}$ & - & $<4$ \\
\hline Sulfate ion & $\mathrm{mg} / \mathrm{kg}$ & - & $<5$ \\
\hline Iron & $\mathrm{mg} / \mathrm{kg}$ & - & $<2$ \\
\hline Sodium & $\mathrm{mg} / \mathrm{kg}$ & & $<$ \\
\hline
\end{tabular}

Source: CTC (1987).

Brazilian model of the integrated production of sugar and ethanol, that has a significant contribution to the competitive stage of our industry today.

\section{Energy}

The evolution of the energy sector of the Brazilian mills and distilleries was as important as the one of the other areas, but in a slower pace due to institutional factors and to the fact that bagasse was an abundant fuel at no cost for the mills that could not find other commercial use for it.

This system was composed by the bagasse fired boilers, backpressure turbines driving the electric generators and the heavier equipment such as mills, knives, shredders, boiler exhaust fans and feed water pumps. The steam at the outlet of the backpressure turbines, at a pressure around $2.5 \mathrm{bar}$, is directed to the process equipment to supply the needs for thermal energy. Figure 6 


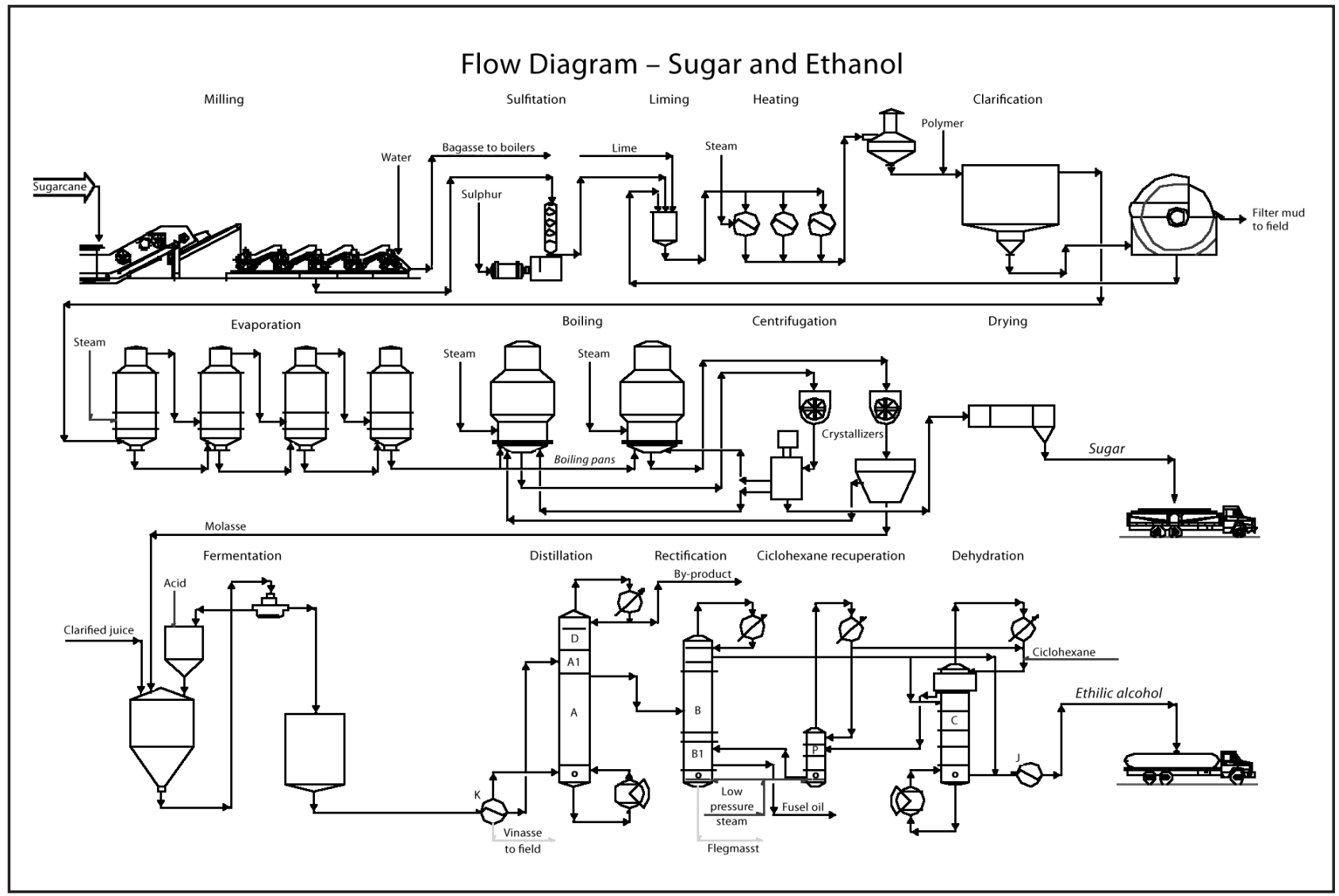

Source: FINGUERUT (2005).

FIGURE 5 Simplified flow diagram of the Brazilian model of the integrated production of sugar and ethanol.

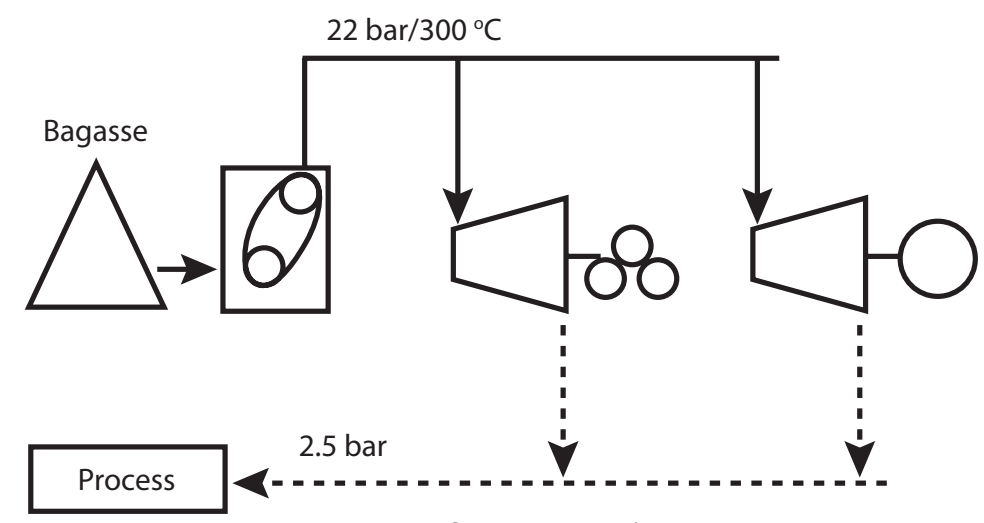

Season operation

FIGURE 6 Simplified flow diagram of the mills energy system.

shows a simplified flow diagram of the mill energy system, in its most common configuration.

Figure 7 presents a simplified energy balance for an average mill in operation today.
From Figure 7 it can be seen that only a fraction of the bagasse primary energy $(585 \mathrm{kWh} / \mathrm{tc})$ is converted into useful energy, in the form of electromechanical energy ( $28 \mathrm{kWh} / \mathrm{tc}$ ), thermal energy 


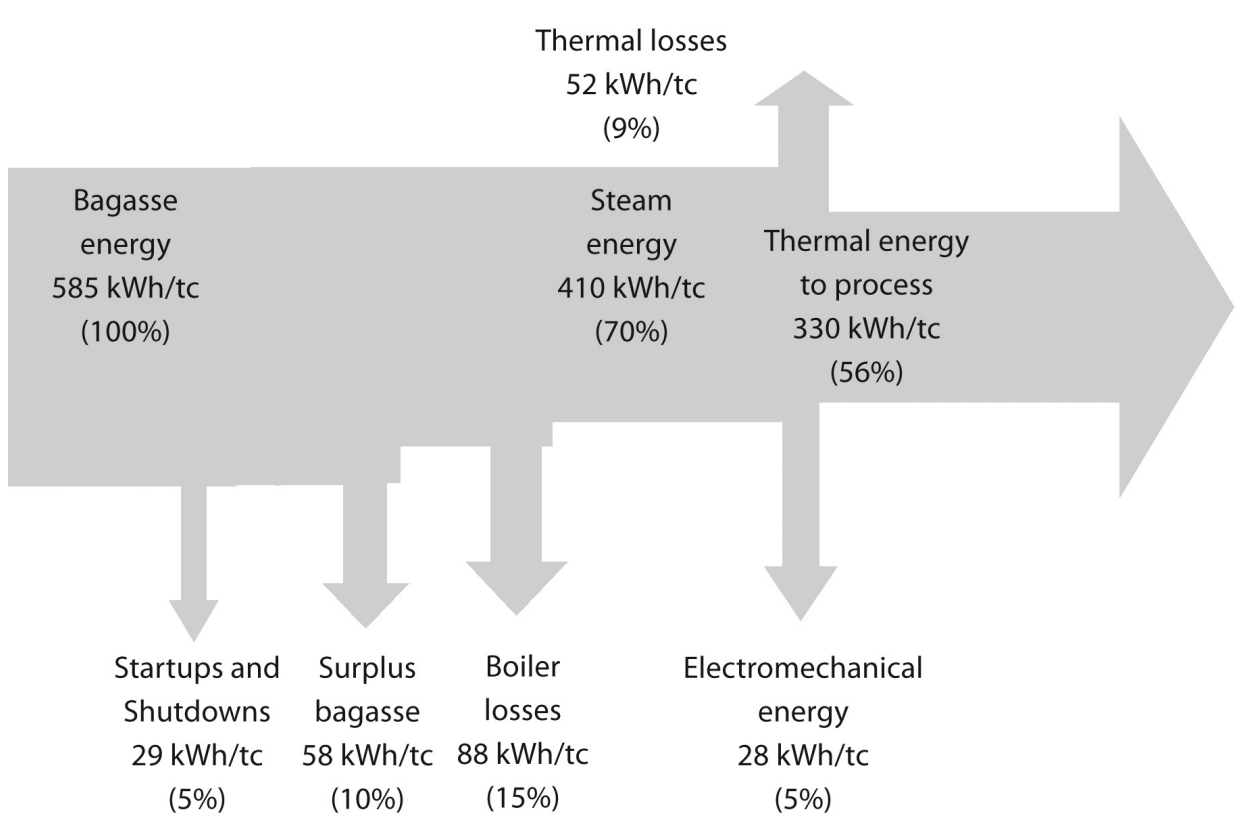

FIGURE 7 Energy balance for a typical mill processing one ton of cane (1 tc).

for process (330 kWh/tc) and surplus bagasse (58 $\mathrm{kWh} / \mathrm{tc}$ ), representing a 70\% recovery.

Sugarcane processing is highly energy intensive, especially in thermal energy for juice concentration, ethanol distillation and dehydration. By the time of Proálcool launching most mills consumed considerable amounts of fuel wood to supplement bagasse in providing fuel for the boilers; besides that, a good part of the electric energy needs of the plant was provided by external electric power bought from the utilities still at low prices. Today the more modern mills generate all the energy needed to run the plant using only bagasse as fuel and still produce some surplus of electric power and bagasse for sale. For a better understanding of how this evolution took place the process will be divided in phases.

Pre-Proálcool phase: prior to 1975 process steam consumption normally reached values around $600 \mathrm{~kg}$ of steam/ton of processed cane (tc), demanding the use of fuel wood to supplement the bagasse for boiler fuel. Boiler steam pressures were in the range of 11 to 22 bar, saturated, and small size boilers dominated ( $<30 \mathrm{t}$ steam/h), with low efficiency $(<70 \%)$ and natural draft, hearth furnace, operating with excess air above $50 \%$; the turbine generators were also small units, seldom above $1 \mathrm{MW}$, with single stage low efficiency turbines. This low efficiency configuration demanded, thus, the external energy in the form of fuel wood and electricity from the grid besides the endogenous source - bagasse.

Self-sufficiency phase: with the increase of the fuel wood and electricity prices the mills sought the improvement of the energy efficiency, initially seeking to phase out the use of fuel wood to depend only on bagasse; since the energy system operated, as is still the case today, in the cogeneration mode the steam consumption reduction had to be followed by the increase in efficiency of the turbine drives (including the turbine generators), to keep the high pressure steam and low pressure steam consumptions balanced. Boiler efficiencies were slowly, but steadily, increased with the installation of heat recovery equipment such as combustion air preheaters and economizers, and with the improvement of the combustion process by the use of secondary air (overfire air), dumping grates, suspension burning and automation. The use of multi stage turbines to drive the main equipment, such as knives, shredders and mills helped to reduce the high pressure steam consumption in this equip- 
ment and to direct this spare steam to the turbine generators to produce more electricity. The use of superheaters became very popular, thus increasing the steam energy content without requiring the increase in boiler pressure (not possible in the existing boilers). The sought self-sufficiency was finally reached by nearly all mills in the mid 1990s, with the following energy profile:

- Boiler steam conditions: 22 bar $/ 300{ }^{\circ} \mathrm{C}$.

- Process steam consumption: $500 \mathrm{~kg} / \mathrm{ton}$ of cane.

- Mechanical energy for the drives: $16 \mathrm{kWh} /$ ton of cane.

- Electric energy for the mill: $12 \mathrm{kWh} / \mathrm{ton}$ of cane.

- Bagasse surplus: 0\% to 10\%.

Surplus power generation phase: the electric sector privatization, started in the mid 1990s, created an institutional and regulatory environment that liberated the electricity market from the Government total control that existed until then, making possible the mills to sell their surplus electricity to other consumers, besides the utility they were connected to. For that it was fundamental the regulation of the Independent Producer and the opening of the national grid to the independent producers requiring only the payment of wheeling tariffs established by the Government through the Regulatory Agency of the sector - Aneel - National Electric Energy Agency. With the intention to diversify country's Energy Matrix the Government created the Proinfa - Program to Incentivize Alternative Energy Sources, facilitating the insertion in the energy matrix of power generation from alternative sources namely biomass, wind power and small hydroelectric power plants $(<30 \mathrm{MW})$. In the case of biomass the response was well below the Government expectations mainly due to the fact that the tariff offered by the program was not considered attractive to the sugarcane sector; on the other side, the open auctions for electricity sale have attracted a significant participation of the mills, causing a fast increase of surplus power generation. For the old mills the modernization of the energy sector is highly dependent on the stage of obsolescence of the boilers and turbine generators, since these items are expensive and have a long useful life, around 30 years. For the new mills BNDES - National Bank for Economic and Social Development, created some differential conditions for the loans favoring the projects that considered the use of boilers with pressures of 60 bar and above; this simple initiative of the bank induced the generalized use of high pressure steam conditions in greenfield mills, avoiding what could have been a regrettable loss of opportunity to increase the sugarcane sector surplus power generation. The standard for the greenfield projects today is steam conditions of $65 \mathrm{bar} / 480^{\circ} \mathrm{C}$ when only backpressure turbine generators are used or $100 \mathrm{bar} / 520{ }^{\circ} \mathrm{C}$ in the case of using condensing/extraction or condensing/backpressure turbine generators. Using only the bagasse available at the mill, the surplus power generation increased from close to zero to values above $80 \mathrm{kWh} /$ ton of cane (see Figure 8). The sugarcane straw recovery is starting slowly and could supplement the bagasse making it possible the year round power generation with a potential to reach surplus power in the range of $150 \mathrm{kWh} / \mathrm{ton}$ of cane. This practice is still incipient and technology development is required to allow its wider use.

Figure 8 illustrates the new mills energy system trends.

These three phases described above required a significant technology development in Brazil, mainly in engineering, to make them happen. This development was relatively easy due to the fact that adequate technology options already existed abroad or even in other sectors of the economy in Brazil; only the adaptation to the mill environment and conditions was required, producing the necessary economies of scale of the national equipment manufacturing industries.

The boilers, as the most expensive item and with a long useful life, evolved slowly because until 2003/2004 the expansion of the sugarcane sector took place essentially by the increase in capacity of the existing mill; the amount of greenfield projects was insignificant. Therefore, the replacement of the existing boilers by more modern and higher pressure units only happened at the end of the useful life of the former; in the initial phase of the Proálcool there was a wide variety of boiler sizes and types, but the small capacity, low pressure, 


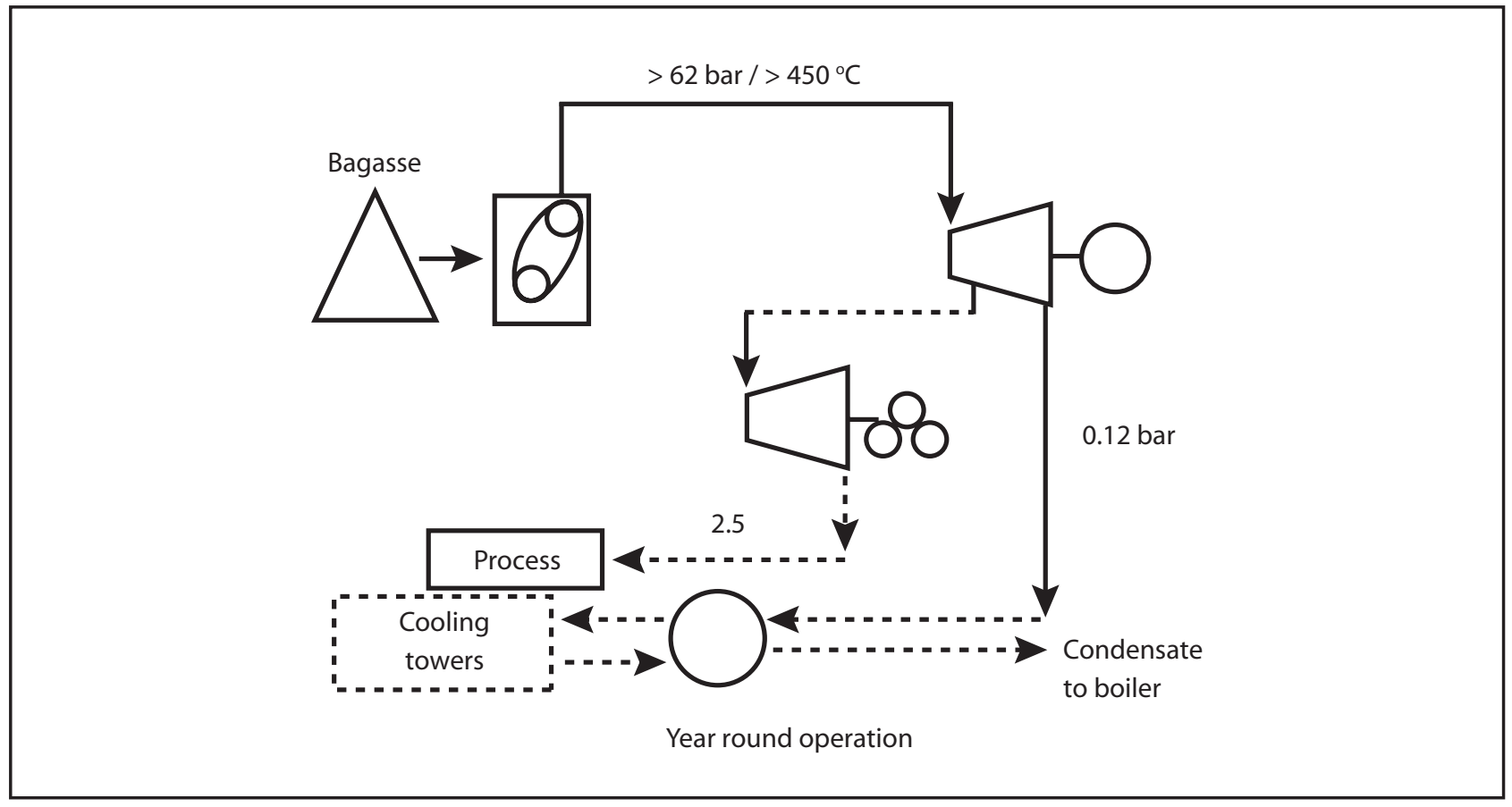

FIGURE 8 Energy system for the new mills.

saturated steam, hearth type furnace, refractory brick walls, natural draft, high excess air, no air preheater or economizer and almost total lack of automation were the prevailing conditions. The first modernization steps were the introduction of air preheater, economizer and superheater, secondary air, dumping grates, forced draft and some automation; these changes had a contribution not only in improving the efficiency but also in the most needed gain in capacity, very useful in mills in the capacity expansion process. Changes to more modern technologies and higher steam pressures were only possible by the time of boiler replacement due to obsolescence. Slower was the introduction of boilers with pressure above 22 bar, suspension burning furnace, membrane wall and full automation (drum level and combustion controls) with thermal efficiencies around 85\%; steam production capacities above 100 t/h became the trend. Today, the state of the art technology offered by the national manufacturers is $100 \mathrm{bar} / 530{ }^{\circ} \mathrm{C}$ steam conditions, single drum design, steam generating capacities up to 400 t/h and efficiencies up to 89\% (DEDINI, 2009); 120 bar $/ 540{ }^{\circ} \mathrm{C}$ boilers are also available but are not being used by the mills.
Turbine generators being equipment costing a lot less than the boilers, having a shorter useful life and having a very active used equipment market had, therefore, a faster rate of modernization by the replacement of equipment even before reaching the end of useful life. The single stage turbine drives for the larger equipment such as shredders, knives and mills are being replaced by multi stage and more efficient turbines (a change from $40 \%$ to $60 \%$, approximately). The turbine generators gained in scale and efficiency by the replacement of the several small single stage units, around 1 MW capacity, from the early Proálcool days with larger (up to 40 MW) multi stage units. The main improvement in mill driving system has been the new trend to use electric motors (either fed by inverters or driving hydraulic motors, to allow the mill speed control); with these upgrades the surplus power generated by the mills using 65 bar $/ 480{ }^{\circ} \mathrm{C}$ steam conditions in pure cogeneration mode (no steam condensing) increased from $40 \mathrm{kWh} /$ ton of cane to $60 \mathrm{kWh} /$ ton of cane, by the use of the steam in the more efficient turbine $(>75 \%)$ in the electric generator rather than in the lower efficiency mill driving turbines (around 60\%). 
TABLE 5 Technological evolution in the mills and distilleries from 1975 to now.

\begin{tabular}{|l|c|c|}
\hline & $\mathbf{1 9 7 5}$ & Today \\
\hline Milling capacity: mill size 6x78" (tc/day) & 5,500 & 15,000 \\
\hline Extraction efficiency (\%) & 93 & 97 \\
\hline Fermentation time (h) & 16 & 8 \\
\hline Fermentation yield (\%) & 82 & 91 \\
\hline Distillation efficiency (\%) & 98 & 99.5 \\
\hline Total plant efficiency (\%) & 66 & 86 \\
\hline Boiler efficiency (\%) & 66 & 89 \\
\hline Turbine generator (\%) & 50 & 75 \\
\hline
\end{tabular}

Source: OLIVÉRIO (2009) e FINGUERUT (2005).

\section{FINAL CONSIDERATIONS}

It is undeniable that there has been an important technological evolution in the Brazilian mills and distilleries, as described above, and it was this development that, together with similar developments in the agricultural and management areas, brought the sugarcane sector in Brazil to the stage of high competitiveness of today. Table 5 summarizes this technological progress in the industrial area, comparing the main indices and parameters evolution from the early days of Proálcool until today.

Seen in this condensed form, the picture of the improvements obtained practically only with a national effort is quite impressive. The high values

\section{REFERENCES}

ANNICCHINO, W. A resposta do empresário aos desafios do Proálcool: o ponto de vista dos produtores (Answer of the businessmen to the PROÁLCOOL Challenges: the producers point of view), Proceedings of Copersucar International Symposium, São Paulo/SP, 1985.

CTC - Centro de Tecnologia Copersucar (Copersucar Technology Center) Proceedings of the I Seminar of Industrial Technology, Piracicaba, São Paulo, 1983.

CTC - Centro de Tecnologia Copersucar (Copersucar Technology Center) Proceedings of the III Seminar of Industrial Technology, Piracicaba, SP, 1987. already reached for the main indices make it very difficult the obtain significant additional gains, but it does not mean that further cost reduction are not possible; improvements in the plant management and operation controls, as well as the increase in surplus power generation (with state of the art technology and sugarcane straw recovery and use to supplement bagasse as fuel) and the gains in economies of scale are helping to continue the cost reduction in the sugarcane processing step to maintain, and even improve, the countries competitiveness in sugar and ethanol production.

This is just a short list contemplating the key issues. A more complete discussion on this subject is presented in CGEE (2009).

DELFINI, P. T. Evolução do sistema de extração (Evolution of the juice extraction system), CTC internal presentation, 2004.

DEDINI INDÚSTRIAS DE BASE. Energy Brochure, 2009. FINGUERUT, J. Simultaneous production of sugar and alcohol from sugarcane, Proceedings of the XXV International Society of Sugarcane Technologists - ISSCT Congress, Guatemala City, Guatemala, January 30 to February 4, 2005.

OLIVÉRIO, J. L. DSM - Dedini Sustainable Mill, BioPower Generation Americas Conference, São Paulo/SP, April 232009 . 